\title{
Correlation between perception of quality of life and social/ demographic/medical variables as well as anti-health behaviours among alcohol-dependent individuals
}

\author{
Marta Makara-Studzińskaํ, Agnieszka J. Kowalska1, Danuta Podstawka', Aneta Pyłypczuk², \\ Zbigniew Śliwiński ${ }^{3}$ \\ ${ }^{1}$ Department of Applied Psychology, Faculty of Nursing and Health Sciences, Medical University of Lublin, Poland \\ Head of Department: Marta Makara-Studzińska MD, PhD \\ ${ }^{2}$ Neuro-psychiatric Hospital, Lublin, Poland \\ Head of Department: Dr. Edward Lewczuk \\ ${ }^{3}$ Manual Therapy Division, Institute of Physiotherapy, Jan Kochanowski University, Kielce, Poland \\ Head of Division: Prof. JKU Zbigniew Śliwiński
}

Key words: dependence, alcohol dependence, quality of life, medical factors.

\begin{abstract}
Introduction: The level of life quality of people with alcohol dependence is significantly influenced by socio-demographic factors such as: gender, marital status and having a family. Additionally promoting anti-health behaviors such as smoking or using psychoactive substances among those with alcohol dependence also reduces the quality of life in this population. Aim of the research: The purpose of this project was to determine the impact of selected psycho-social and medical factors on the quality of life in alcohol-dependent patients in relation to the duration of abstinence. Study data served to determine whether there is a correlation between the presence of selected psycho-social and medical factors and a patient's subjective perception of his/her quality of life.

Material and methods: The study involved alcohol-dependent patients undergoing treatment in the Residential Alcohol Addiction Therapy Department of the Neuropsychiatric Hospital in Lublin. In the first stage of the study, the severity of the alcohol problem was assessed with the MAST and CAGE tests and quality of life was assessed with the SF-36 questionnaire. An Original Socio-Demographic Questionnaire was also used. In the second stage of the study, the SF-36 scale was used to evaluate the quality of life. The Original Socio-Demographic Questionnaire was also used.

Results: The socio-economic factors that had a statistically significant impact on the quality of life of the alcohol-dependent individuals comprised sex, marital status and having a family. Marital status was shown to be one of the most important family-related factors significantly influencing the quality of life. Having a family was not a factor associated with subjective improvement of the quality of life during abstinence for alcohol-dependent individuals. Awareness of socio-economic and medical factors influencing quality of life in individuals addicted to alcohol and gambling is an important component of assistance given to those people. It allows the therapeutic plan to be adjusted to the individual needs of each patient, which increases treatment efficacy.

Conclusions: A significant influence of the socio-demographic factors such as gender or marital status on the quality of life of people with alcohol dependence was observed. A positive correlation between promoting anti-health behavior such as smoking or using psychoactive substances and the level of life quality of people with alcohol dependence was noted.
\end{abstract}

\section{Introduction}

The ever increasing pace of life, the desire to escape unwanted emotional states, the quest for easy pleasure and difficulty controlling impulse behaviours have altered the functioning of contemporary man. More and more behaviours are compulsive, often pathological, and thus have a negative effect on various spheres of functioning of an individual. The International Classification of Diseases (ICD-10) defines dependence as a cluster of physiological, behavioural, and cognitive phenomena in which the use of a substance or undertaking a particular activ- ity takes on a much higher priority for a given individual than other behaviours that once had greater value. The main symptom of dependence is the desire to take a psychoactive substance or undertake a particular activity [1]. Dependence is a chronic disorder that progresses if it is not treated. Substance dependence [2] is an acquired overpowering need to use a particular substance [3, 4]. Alcohol is currently the most commonly available psychoactive substance. Alcohol abuse and alcohol dependence are serious public health problems at present. Many of those abusing alcohol do not realise that they crossed the boundary of harmless use a long time ago [5]. In the $19^{\text {th }}$ century, 
alcoholism came to be regarded as a major threat to general health. Nowadays, forms of substance dependence known for many years (alcohol, medications, narcotic drugs) have been accompanied by so-called behavioural, or functional, dependence, including pathological gambling, workaholism, shopaholism, sexaholism and the recently growing dependence on the computer or the Internet [2]. The most common form of behavioural dependence is pathological gambling $[6,7]$. The present study was prompted by the need to identify factors that determine the functioning and quality of life of addicted patients at different stages of abstinence. It showed that an evaluation of the patient's quality of life is an important component of treatment. This evaluation aims to improve the patient's overall situation rather than concentrating solely on removing the symptoms of disease. A quality of life assessment allows the implementation of a more directed therapeutic intervention and empowers the patient as a party to the treatment by attempting to meet his or her real needs. The contemporary concept of the quality of life is founded on the departure from viewing health as the absence of disease and adopting a holistic view of health as a state of full physical, mental and social well-being. In 1991, the WHO proposed the following precise definition of the quality of life: "individuals' perception of their position in life in the context of the culture and value systems in which they live and in relation to their goals, expectations, standards and concerns. It is a broad ranging concept influencing the person's physical health, psychological state, level of independence, and relations with other people and salient features of the environment" [8].

\section{Aim of the research}

The aim of the research was to determine the impact of selected psychosocial and medical factors on the quality of life of alcohol-dependent patients in relation to the duration of abstinence. Study data served to determine whether there is a correlation between the presence of selected psycho-social and medical factors and a patient's subjective perception of his/her quality of life.

\section{Material and methods}

The study was carried out between July 2011 and May 2012. It involved 101 subjects, of whom $37.62 \%$ $(n=38)$ were addicted to alcohol, $30.69 \%(n=31)$ were addicted to gambling and alcohol, and $31.69 \%(n=32)$ were addicted to gambling. All participants had been abstinent for various periods. The study tools were administered in two stages 6-8 months apart. The present paper discusses only the results obtained from the alcohol-dependent participants $(n=38)$. Invitation to participate was offered to current and past patients of the Residential Alcohol Addiction Therapy Department and to members of Gamblers Anonymous self-help groups from Lublin, Łuków and Zamość. In the first stage, the MAST and CAGE tests were used to assess the severity of the alcohol problem. The SF-36 survey was used to assess the quality of life. An Original Socio-Demographic Questionnaire was also used. In the second stage of the study, the SF-36 scale was used to evaluate the quality of life. The Original Socio-Demographic Questionnaire was also used.

\section{Statistical analysis}

The raw data were subjected to a statistical analysis. The values of measurable parameters were summarised as means and standard deviations, and those of non-measurable parameters were described in terms of numbers and percentages. The normality of distributions for measurable data was assessed with the Shapiro-Wilk $W$ test. The Mann-Whitney $U$ test was used to compare two independent samples, while the Kruskal-Wallis test was used to compare more than two groups. Correlations between variables were assessed with Spearman's correlation analysis $(R)$. For unrelated qualitative parameters, differences between the groups were analysed with the $\chi^{2}$ test of homogeneity. The presence of correlations between parameters was analysed with the $\chi^{2}$ test of independence. Step-wise regression analysis was used to assess the percentage of predicted variance and identify factors accounting for the physical and mental aspects of the quality of life, with the exclusion criterion for $F$ at $p>0.01$. The results of regression analysis were presented as values of the adjusted coefficient of determination $\left(R^{2}\right)$, which corresponds to the percentage of the dependent variable predicted by the independent variables in the model, and the values of coefficients of parameters of the model (Beta). The values and significance levels of $t$ test statistics (testing the significance of each parameter of the equation) were also given, as were the values and significance levels of the $F$ test, which tests the values of all parameters collectively. Additionally, the value of the partial correlation coefficient was also given as an index of the contribution of a given independent variable to the variance of the dependent variable. The significance level, indicating statistically significant differences or correlations, was set at $p<0.05$. The database and statistical analyses were performed with Statistica 9.0 (StatSoft, Polska).

\section{Results}

Factors influencing the quality of life of alcoholdependent patients were analysed. The correlation between perceived quality of life and such sociodemographic data as gender, age, having children, having a family and accommodation, and anti-health 
Table 1. SF-36 scores of alcohol-addicted respondents in the $1^{\text {st }}$ stage of the study with regard to gender

\begin{tabular}{|c|c|c|c|c|c|c|c|c|}
\hline \multirow[t]{2}{*}{ Domains } & \multicolumn{3}{|c|}{ Women } & \multicolumn{3}{|c|}{ Men } & \multicolumn{2}{|c|}{ Statistical analysis } \\
\hline & Mean & Median & SD & Mean & Median & SD & $Z$ & $p$ \\
\hline PF & 76.25 & 75.00 & 11.09 & 82.35 & 90.00 & 19.20 & -1.28 & 0.20 \\
\hline RP & 54.69 & 59.38 & 27.18 & 60.48 & 62.50 & 27.21 & -0.31 & 0.76 \\
\hline BP & 40.00 & 40.00 & 11.55 & 51.47 & 50.00 & 21.05 & -1.12 & 0.26 \\
\hline $\mathrm{GH}$ & 51.25 & 47.50 & 13.15 & 47.94 & 50.00 & 17.06 & 0.31 & 0.76 \\
\hline VT & 46.88 & 46.88 & 24.21 & 44.49 & 43.75 & 18.45 & 0.07 & 0.94 \\
\hline SF & 37.50 & 37.50 & 30.62 & 52.21 & 50.00 & 25.46 & -0.90 & 0.37 \\
\hline RE & 41.67 & 41.67 & 13.61 & 61.76 & 66.67 & 26.60 & -1.78 & 0.07 \\
\hline $\mathrm{MH}$ & 56.25 & 60.00 & 19.31 & 48.53 & 50.00 & 17.65 & 0.86 & 0.39 \\
\hline
\end{tabular}

Table 2. SF-36 scores of alcohol-addicted respondents in the $2^{\text {nd }}$ stage of the study with regard to gender

\begin{tabular}{|c|c|c|c|c|c|c|c|c|}
\hline \multirow[t]{2}{*}{ Domains } & \multicolumn{3}{|c|}{ Women } & \multicolumn{3}{|c|}{ Men } & \multicolumn{2}{|c|}{ Statistical analysis } \\
\hline & Mean & Median & SD & Mean & Median & SD & $Z$ & $p$ \\
\hline PF & 98.33 & 100.0 & 2.89 & 84.80 & 95.00 & 23.12 & 1.15 & 0.25 \\
\hline RP & 79.17 & 75.0 & 13.01 & 65.00 & 62.50 & 21.35 & 1.19 & 0.23 \\
\hline BP & 66.67 & 70.0 & 15.28 & 56.40 & 60.00 & 23.78 & 0.52 & 0.60 \\
\hline $\mathrm{GH}$ & 53.33 & 55.0 & 2.89 & 52.00 & 50.00 & 18.20 & 0.78 & 0.44 \\
\hline VT & 50.00 & 50.0 & 6.25 & 45.50 & 43.75 & 22.06 & 0.30 & 0.77 \\
\hline SF & 66.67 & 62.5 & 31.46 & 66.00 & 75.00 & 27.13 & 0.00 & 1.00 \\
\hline RE & 61.11 & 58.3 & 12.73 & 66.67 & 66.67 & 24.53 & -0.63 & 0.53 \\
\hline $\mathrm{MH}$ & 58.33 & 65.0 & 16.07 & 59.00 & 55.00 & 28.65 & 0.00 & 1.00 \\
\hline
\end{tabular}

behaviours (tobacco smoking, exposure to psychoactive substances) was analysed. The correlation between quality of life and medical variables (taking medications, participation in therapy) was also investigated.

\section{Correlation between perceived quality of life and sociodemographic variables: gender}

The statistical analysis revealed that, in Stage 1 of the study, the quality of life of alcohol-dependent men was slightly better than that of women with regard to PF (physical function), RP (role physical physical limitations of one's social role), BP (bodily pain), SF (social functioning) and RE (role emotional - emotional limitations of one's social role), while women reported slightly better quality of life in the domains of GH (general health), VT (vitality) and $\mathrm{MH}$ (mental health). The differences between the genders were, however, not statistically significant $(p>0.05)$ (Table 1).

The repeat survey administered in the $2^{\text {nd }}$ stage of the study found that the quality of life of men was slightly better in the SF and RE domains, while women reported slightly better quality of life in the remaining domains. However, these differences were not statistically significant $(p>0.05)$ (Table 2$)$.

\section{Age}

The analysis did not reveal a significant correlation between perceived quality of life (in all domains) and age in the first stage of the study $(p>0.05)$. A repeat analysis in the $2^{\text {nd }}$ stage of the study also failed to reveal a significant correlation between quality of life assessment of alcohol-dependent patients and age in all domains of the SF-36 $(p>0.05)$.

\section{Having children}

The surveys showed that, in the $1^{\text {st }}$ stage of the study, better quality of life in all domains was perceived by those alcohol-addicted respondents who did not have children. There were significant differences in the quality of life domains of bodily pain $(p=0.03)$, overall health $(p=0.04)$ and social function- 
Table 3. SF-36 scores of alcohol-addicted respondents in the $1^{\text {st }}$ stage of the study with regard to having children

\begin{tabular}{|c|c|c|c|c|c|c|c|c|}
\hline \multirow[t]{2}{*}{ Domains } & \multicolumn{3}{|c|}{ Has children } & \multicolumn{3}{|c|}{ Does not have children } & \multicolumn{2}{|c|}{ Statistical analysis } \\
\hline & Mean & Median & SD & Mean & Median & SD & $Z$ & $p$ \\
\hline PF & 79.11 & 80.00 & 19.01 & 89.00 & 95.00 & 15.60 & -1.84 & 0.07 \\
\hline RP & 57.59 & 59.38 & 27.81 & 66.25 & 68.75 & 24.33 & -0.88 & 0.38 \\
\hline BP & 46.07 & 50.00 & 18.33 & 62.00 & 70.00 & 22.51 & -2.20 & 0.03 \\
\hline $\mathrm{GH}$ & 44.82 & 42.50 & 15.84 & 58.00 & 57.50 & 15.31 & -2.11 & 0.04 \\
\hline VT & 41.74 & 40.63 & 19.62 & 53.13 & 53.13 & 13.58 & -1.62 & 0.10 \\
\hline SF & 45.09 & 43.75 & 25.76 & 66.25 & 68.75 & 20.45 & -2.17 & 0.03 \\
\hline RE & 57.14 & 58.33 & 26.03 & 66.67 & 70.83 & 26.64 & -1.04 & 0.30 \\
\hline $\mathrm{MH}$ & 47.86 & 50.00 & 17.50 & 53.50 & 47.50 & 18.57 & -0.66 & 0.51 \\
\hline
\end{tabular}

Table 4. SF-36 scores of alcohol-addicted respondents in the $2^{\text {nd }}$ stage of the study with regard to having children

\begin{tabular}{|c|c|c|c|c|c|c|c|c|}
\hline \multirow[t]{2}{*}{ Domains } & \multicolumn{3}{|c|}{ Has children } & \multicolumn{3}{|c|}{ Does not have children } & \multicolumn{2}{|c|}{ Statistical analysis } \\
\hline & Mean & Median & SD & Mean & Median & SD & $Z$ & $p$ \\
\hline PF & 84.76 & 95.00 & 24.57 & 90.71 & 100.0 & 13.36 & -0.42 & 0.67 \\
\hline RP & 69.35 & 68.75 & 22.44 & 58.04 & 56.3 & 13.36 & 1.17 & 0.24 \\
\hline BP & 58.10 & 60.00 & 23.16 & 55.71 & 60.0 & 24.40 & 0.19 & 0.85 \\
\hline $\mathrm{GH}$ & 54.29 & 50.00 & 18.99 & 45.71 & 50.0 & 7.87 & 1.14 & 0.25 \\
\hline VT & 48.21 & 50.00 & 21.12 & 39.29 & 43.8 & 20.32 & 0.93 & 0.35 \\
\hline SF & 66.67 & 75.00 & 27.48 & 64.29 & 75.0 & 27.41 & 0.24 & 0.81 \\
\hline RE & 66.67 & 66.67 & 25.14 & 64.29 & 66.7 & 19.07 & 0.32 & 0.75 \\
\hline $\mathrm{MH}$ & 64.29 & 70.00 & 28.16 & 42.86 & 50.0 & 17.99 & 1.83 & 0.07 \\
\hline
\end{tabular}

Table 5. SF-36 scores of alcohol-addicted respondents in the $1^{\text {st }}$ stage of the study with regard to living with family

\begin{tabular}{|c|c|c|c|c|c|c|c|c|}
\hline \multirow[t]{2}{*}{ Domains } & \multicolumn{3}{|c|}{ Lives alone } & \multicolumn{3}{|c|}{ Lives with family } & \multicolumn{2}{|c|}{ Statistical analysis } \\
\hline & Mean & Median & SD & Mean & Median & SD & $Z$ & $p$ \\
\hline PF & 90.71 & 95.00 & 9.76 & 79.68 & 80.00 & 19.49 & -1.37 & 0.17 \\
\hline RP & 66.96 & 68.75 & 24.66 & 58.27 & 56.25 & 27.50 & -0.77 & 0.44 \\
\hline BP & 62.86 & 70.00 & 21.38 & 47.42 & 50.00 & 19.49 & -1.77 & 0.08 \\
\hline $\mathrm{GH}$ & 59.29 & 65.00 & 21.68 & 45.81 & 50.00 & 14.50 & -1.62 & 0.11 \\
\hline VT & 56.25 & 62.50 & 16.14 & 42.14 & 43.75 & 18.54 & -1.90 & 0.06 \\
\hline SF & 71.43 & 75.00 & 22.49 & 45.97 & 50.00 & 24.66 & -2.37 & 0.02 \\
\hline RE & 71.43 & 83.33 & 28.81 & 56.99 & 58.33 & 25.29 & -1.32 & 0.19 \\
\hline $\mathrm{MH}$ & 57.86 & 50.00 & 20.38 & 47.42 & 50.00 & 16.83 & -1.19 & 0.24 \\
\hline
\end{tabular}

ing $(p=0.03)$, while the scores in the remaining domains did not differ significantly $(p>0.05)$ (Table 3$)$.

The repeat survey in the $2^{\text {nd }}$ stage of the study showed better perceived quality of life with regard to most SF-36 domains among those alcohol-addicted respondents who did not have children, with the exception of the domains of MH, RP and VT. The analysis did not show significant differences between the two 
Table 6. SF-36 scores of alcohol-dependent respondents with regard to tobacco smoking status

\begin{tabular}{|c|c|c|c|c|c|c|c|c|}
\hline \multirow[t]{2}{*}{ Domains } & \multicolumn{3}{|c|}{ Smokers } & \multicolumn{3}{|c|}{ Non-smokers } & \multicolumn{2}{|c|}{ Statistical analysis } \\
\hline & Mean & Median & SD & Mean & Median & SD & $Z$ & $p$ \\
\hline PF & 80.86 & 90.00 & 20.40 & 84.44 & 80.00 & 10.74 & 0.00 & 1.00 \\
\hline RP & 60.78 & 62.50 & 28.24 & 56.94 & 50.00 & 23.27 & -0.57 & 0.57 \\
\hline BP & 48.28 & 50.00 & 20.71 & 56.67 & 50.00 & 19.36 & 0.98 & 0.33 \\
\hline $\mathrm{GH}$ & 47.24 & 50.00 & 17.09 & 51.67 & 50.00 & 15.21 & 0.67 & 0.50 \\
\hline VT & 40.73 & 43.75 & 18.35 & 57.64 & 62.50 & 14.24 & 2.37 & 0.02 \\
\hline SF & 48.28 & 50.00 & 26.67 & 58.33 & 62.50 & 23.39 & 0.96 & 0.34 \\
\hline RE & 59.77 & 66.67 & 27.73 & 59.26 & 58.33 & 21.83 & -0.29 & 0.77 \\
\hline $\mathrm{MH}$ & 45.86 & 45.00 & 15.06 & 60.56 & 70.00 & 21.71 & 2.11 & 0.03 \\
\hline
\end{tabular}

Table 7. SF-36 scores of alcohol-addicted respondents with regard to psychoactive substance exposure

\begin{tabular}{|c|c|c|c|c|c|c|c|c|}
\hline \multirow[t]{2}{*}{ Domains } & \multicolumn{3}{|c|}{$\begin{array}{c}\text { Exposure to psychoactive } \\
\text { substances }\end{array}$} & \multicolumn{3}{|c|}{$\begin{array}{l}\text { No exposure to psychoactive } \\
\text { substances }\end{array}$} & \multicolumn{2}{|c|}{ Statistical analysis } \\
\hline & Mean & Median & SD & Mean & Median & SD & $z$ & $p$ \\
\hline PF & 82.06 & 90.00 & 16.78 & 81.43 & 90.00 & 20.20 & -0.09 & 0.93 \\
\hline RP & 56.25 & 50.00 & 29.40 & 62.80 & 68.75 & 25.04 & -0.76 & 0.45 \\
\hline BP & 44.71 & 50.00 & 19.40 & 54.76 & 50.00 & 20.64 & -1.31 & 0.19 \\
\hline $\mathrm{GH}$ & 42.06 & 45.00 & 13.35 & 53.33 & 55.00 & 17.49 & -1.94 & 0.05 \\
\hline VT & 36.03 & 37.50 & 13.89 & 51.79 & 62.50 & 19.48 & -2.86 & 0.004 \\
\hline SF & 38.97 & 37.50 & 24.16 & 60.12 & 62.50 & 23.92 & -2.51 & 0.01 \\
\hline RE & 51.96 & 58.33 & 26.77 & 65.87 & 66.67 & 24.57 & -1.48 & 0.14 \\
\hline $\mathrm{MH}$ & 40.59 & 40.00 & 13.45 & 56.43 & 55.00 & 17.83 & -2.61 & 0.01 \\
\hline
\end{tabular}

groups with regard to individual aspects of the quality of life $(p>0.05)$ (Table 4$)$.

\section{Living with family}

In the $1^{\text {st }}$ stage of the study, the SF-36 revealed that respondents who lived alone reported better quality of life across all domains compared to those respondents who lived with their families. Statistically significant differences were found only with regard to social functioning $(p=0.02)$ and there was a nearsignificant difference with regard to vitality $(p=0.06)$ (Table 5).

The repeat survey in the $2^{\text {nd }}$ stage of the study revealed that respondents living alone reported better quality of life in all domains except PF than those who lived with their families. The statistical analysis did not reveal significant differences between these groups with regard to individual domains of the quality of life $(p>0.05)$.

\section{Correlation between quality of life assessment and selected anti-health behaviours: tobacco smoking}

The statistical analysis in the $1^{\text {st }}$ and $2^{\text {nd }}$ stage of the study showed that alcohol-dependent respondents who did not smoke tobacco reported better quality of life in all domains compared to those who smoked. There were significant differences with regard to vitality $(p=0.02)$ and mental health $(p=0.03)$, with non-significant differences in all the remaining domains $(p>0.05)$ (Table 6).

\section{Exposure to psychoactive substances}

The statistical analysis in the $1^{\text {st }}$ and $2^{\text {nd }}$ stage of the study showed that alcohol-dependent respondents who had not been exposed to psychoactive substances reported better quality of life in all domains compared to respondents who had been exposed to 
Table 8. SF-36 scores of alcohol-dependent respondents with regard to taking psychiatric medications

\begin{tabular}{|c|c|c|c|c|c|c|c|c|}
\hline \multirow[t]{2}{*}{ Domains } & \multicolumn{3}{|c|}{ Takes psychiatric medications } & \multicolumn{3}{|c|}{$\begin{array}{c}\text { Does not take psychiatric } \\
\text { medications }\end{array}$} & \multicolumn{2}{|c|}{ Statistical analysis } \\
\hline & Mean & Median & SD & Mean & Median & SD & $Z$ & $p$ \\
\hline PF & 57.50 & 57.50 & 10.61 & 83.06 & 90.00 & 17.98 & 1.90 & 0.06 \\
\hline RP & 12.50 & 12.50 & 8.84 & 62.50 & 65.63 & 25.04 & 2.16 & 0.03 \\
\hline BP & 20.00 & 20.00 & 14.14 & 51.94 & 50.00 & 19.54 & 1.93 & 0.05 \\
\hline $\mathrm{GH}$ & 30.00 & 30.00 & 21.21 & 49.31 & 50.00 & 16.04 & 1.37 & 0.17 \\
\hline VT & 12.50 & 12.50 & 8.84 & 46.53 & 46.88 & 17.52 & 2.19 & 0.03 \\
\hline SF & 18.75 & 18.75 & 26.52 & 52.43 & 50.00 & 25.15 & 1.54 & 0.12 \\
\hline RE & 12.50 & 12.50 & 17.68 & 62.27 & 66.67 & 24.11 & 2.12 & 0.03 \\
\hline $\mathrm{MH}$ & 27.50 & 27.50 & 3.54 & 50.56 & 50.00 & 17.39 & 1.83 & 0.07 \\
\hline
\end{tabular}

Table 9. SF-36 scores of alcohol-dependent respondents in the $1^{\text {st }}$ stage of the study with regard to attending any form of therapy for dependence

\begin{tabular}{|c|c|c|c|c|c|c|c|c|}
\hline \multirow[t]{2}{*}{ Domains } & \multicolumn{3}{|c|}{ Attends therapy } & \multicolumn{3}{|c|}{ Does not attend therapy } & \multicolumn{2}{|c|}{ Statistical analysis } \\
\hline & Mean & Median & SD & Mean & Median & SD & $Z$ & $p$ \\
\hline PF & 83.61 & 90.00 & 15.75 & 47.50 & 47.50 & 38.89 & 1.73 & 0.08 \\
\hline $\mathrm{RP}$ & 62.50 & 65.63 & 24.91 & 12.50 & 12.50 & 17.68 & 2.09 & 0.04 \\
\hline BP & 50.83 & 50.00 & 20.75 & 40.00 & 40.00 & 14.14 & 0.75 & 0.45 \\
\hline $\mathrm{GH}$ & 48.33 & 50.00 & 16.78 & 47.50 & 47.50 & 17.68 & 0.00 & 1.00 \\
\hline VT & 46.53 & 46.88 & 17.32 & 12.50 & 12.50 & 17.68 & 1.99 & 0.05 \\
\hline SF & 53.12 & 50.00 & 24.34 & 6.25 & 6.25 & 8.84 & 2.19 & 0.03 \\
\hline RE & 62.27 & 66.67 & 24.11 & 12.50 & 12.50 & 17.68 & 2.12 & 0.03 \\
\hline $\mathrm{MH}$ & 50.97 & 50.00 & 16.68 & 20.00 & 20.00 & 7.07 & 2.22 & 0.03 \\
\hline
\end{tabular}

psychoactive substances. There were significant differences in perceived quality of life with regard to vitality $(p=0.004)$, social functioning $(p=0.01)$, and mental health $(p=0.01)$, and near significant differences with regard to overall health $(p=0.05)$, without significant differences in perceived quality of life in the remaining domains $(p>0.05)$ (Table 7).

Quality of life and medical variables: taking psychiatric medications

The surveys showed that, in the $1^{\text {st }}$ and $2^{\text {nd }}$ stage of the study, participants who did not take psychiatric medications reported better quality of life in all domains compared to those participants receiving psychiatric medications. There were significant differences in the assessment of quality of life in the domains of physical limitations to social roles $(p=0.03)$, vitality $(p=0.03)$ and mental limitations to social roles $(p=0.03)$, and near significant differences in the domains of bodily pain $(p=0.05)$ and physical function $(p=0.06)$ (Table 8).

\section{Participation in selected forms of therapy for dependence}

The survey in the $1^{\text {st }}$ stage revealed that respondents who participated in any form of therapy reported better quality of life in all domains compared with respondents who did not participate in therapy. The statistical analysis revealed significant differences in quality of life assessment with regard to the domains of physical limitations to one's social role $(p=0.04)$, vitality $(p=0.05)$, SF $(p=0.03)$, emotional limitations to one's social role $(p=0.03)$ and $\mathrm{MH}(p=0.03)$, while the remaining domains of quality of life did not differ significantly between the groups $(p>0.05)$ (Table 9).

The repeat survey in Stage 2 showed that respondents who used any kind of assistance (therapy groups, support groups, self-help groups) reported 
Table 10. SF-36 scores of alcohol-dependent respondents in the $2^{\text {nd }}$ stage of the study with regard to attending any form of therapy for dependence

\begin{tabular}{|c|c|c|c|c|c|c|c|c|}
\hline \multirow[t]{2}{*}{ Domains } & \multicolumn{3}{|c|}{ Attends therapy } & \multicolumn{3}{|c|}{ Does not attend therapy } & \multicolumn{2}{|c|}{ Statistical analysis } \\
\hline & Mean & Median & SD & Mean & Median & SD & $Z$ & $p$ \\
\hline $\mathrm{PF}$ & 83.93 & 92.50 & 24.98 & 88.57 & 97.50 & 19.75 & -0.62 & 0.54 \\
\hline RP & 70.54 & 71.88 & 22.92 & 62.50 & 56.25 & 18.67 & 1.17 & 0.24 \\
\hline BP & 57.14 & 65.00 & 24.94 & 57.86 & 60.00 & 21.90 & 0.00 & 1.00 \\
\hline $\mathrm{GH}$ & 53.93 & 50.00 & 21.59 & 50.36 & 50.00 & 11.84 & 0.32 & 0.75 \\
\hline VT & 54.46 & 56.25 & 16.52 & 37.50 & 34.38 & 21.93 & 2.11 & 0.03 \\
\hline SF & 70.54 & 81.25 & 28.00 & 61.61 & 75.00 & 26.16 & 0.99 & 0.32 \\
\hline RE & 71.43 & 70.83 & 21.11 & 60.71 & 58.33 & 25.20 & 1.19 & 0.23 \\
\hline $\mathrm{MH}$ & 65.00 & 67.50 & 15.93 & 52.86 & 47.50 & 34.96 & 1.79 & 0.07 \\
\hline
\end{tabular}

better quality of life in all domains except PF compared to respondents who did not use any kind of assistance. The statistical analysis revealed significant differences in perceived quality of life with regard to VT $(p=0.03)$ and non-statistically significant differences in the remaining domains $(p>0.05)$ (Table 10).

\section{Discussion}

Assessment of the quality of life, i.e. a comprehensive self-evaluation of one's physical and emotional health, independence in life and the degree of freedom from reliance on others, as well as personal beliefs, is useful in monitoring overall health and outcomes of treatment of addicted patients. Disturbance of functioning even in one of these domains has a negative effect on the quality of life. Several studies have compared the quality of life of alcohol-dependent individuals with that of other populations, including the general population [8-10], showing that the quality of life of alcohol-dependent individuals is worse than in the general population. Other studies [13-15] have compared the quality of life of alcoholdependent and alcohol-abusing individuals, revealing that alcohol dependents had much worse quality of life, especially in the mental health domain [13]. The severity of dependence was inversely proportional to the quality of life [14]. Still other studies have shown that the inferior quality of life is related to the dependence itself rather than to its severity [15]. Debate continues on what factors disturb the quality of life of addicted patients or have a considerable effect on improving the quality of life. It has been found that a deterioration in the quality of life of addicted patients measured with the SF-36 is associated with physical limitations to one's social roles, vitality, social functioning and emotional limitations to one's social roles $[15,16]$. The present study partially confirms these findings since it was demonstrated that alcohol-dependent patients reported the best quality of life with regard to physical function and the worst in the domains of vitality and mental health. Statistical analysis revealed significant differences in the perceived quality of life with regard to mental health $(p=0.02)$ and near significant differences with regard to physical function $(p=0.05)$. This indicates that mental well-being is a significant area that influences the quality of life irrespective of the addictive factor. Opinions differ regarding the role of socioeconomic factors and their influence on the functioning of addicted patients. Rudolph et al. [17] found that gender had an effect on the quality of life of addicted individuals. Women's subjective perception of their quality of life differs from men's and varies with age and occupational and financial standing. The needs of the two genders are also different, which is also reflected in their perception of the quality of life. Studies show an inferior quality of life of addicted men compared to addicted women [2, 17-19]. The present study confirmed the thesis with regard to gender. The quality of life of men was found to be slightly better than that of women in the domains of PF, RP, BP, SF and $\mathrm{RE}$, while women reported slightly better quality of life in the domains of GH, VT and MH. These differences, however, were not statistically significant $(p>0.05)$. Available studies also show that the quality of life of addicted individuals deteriorates with age. The younger the age at which dependence developed, the poorer the level of functioning and, consequently, the quality of life of addicted individuals in later life [19]. This correlation is logical as there is an increasing incidence of dependence among young people, whose personalities are not yet stable, and the dependence disturbs the development of their personalities, which significantly affects their functioning in later life. The present study did not confirm the first thesis with regard to age since it failed to show a significant correlation between the quality of life and age of alcohol-dependent patients $(p>0.05)$.

Professionals working with addicted patients believe that external sources of support such as family, children or friends are an important element of thera- 
peutic success. Close relatives and friends not only offer support but also importantly contribute to the patient's motivation to remain abstinent and to undergo and continue treatment. A study of the quality of life of alcohol-dependent individuals found that subjects who did not have a family or children had a worse quality of life [20]. The results of the present study confirm the first thesis with regard to having a family, which influences the quality of life of alcohol-dependent individuals. On the one hand, having a family has a positive effect on the addicted individual, but on the other it is associated with important emotional sequelae of the dependence resulting from inappropriate execution of roles, such as a sense of guilt, shame, and self-anger, which considerably worsen the quality of life of the addicted individual [21-23]. This explains why subjects living alone reported a better quality of life. Statistically significant differences were revealed with regard to social functioning, with those living alone having much fewer roles to play compared to those living with their families, as well as in regard to vitality and mental health. The present study confirms the first hypothesis.

The study found improved quality of life across all domains among those taking part in various forms of treatment of alcohol dependence. Similar results were obtained by Chodkiewicz and Wnuk [21-23].

\section{Conclusions}

Gender was found to be a sociodemographic factor influencing the quality of life of alcohol-dependent individuals. A negative correlation was found between tobacco smoking in the study population and the quality of life, with non-smokers enjoying a better quality of life. Marital status had a significant influence on the quality of life in the study population. Alcohol-dependent individuals who had never used psychoactive substances had a better quality of life. Alcohol-dependent individuals who took psychiatric medications had a worse quality of life. Involvement in various forms of dependence therapy had a positive effect on the quality of life in the study population.

\section{References}

1. Bilikiewicz A, Pużyński S, Rybakowski J, et al. Psychiatria. Urban \& Partner, Wrocław 2002.

2. Ognińska-Bulik N. Osobowość typu D a ryzyko uzależnienia odczynności. Psychiatria 2010; 7: 11-24.

3. Woronowicz B. Uzależnienia. Geneza, terapia, powrót do zdrowia. Media Rodzina, Poznań 2009.

4. Baumeister RF, Heatherton TF, Tice DM. Utrata kontroli. Jak i dlaczego tracimy zdolność samoregulacji. PARPA, Warszawa 2000.

5. Płachecka L. Jakość życia osób z uzależnieniem alkoholowym i ich rodzin. Zdr Publ 2004; 114: 388-393.

6. Niewiadomska I, Brzezinska M, Lelonek B. Hazard. KUL, Lublin 2005.
7. Petry N. Pathological gambling - etiology, comorbidity, treatment. American Psychological Association, Washington DC 2004; 4-13.

8. Dobrzyńska E, Rymaszewska J, Kiejna A. Problem jakości życia osób z zaburzeniami psychicznymi. Adv Clin Exp Med 2007; 16: 173-178.

9. Foster JH, Marshall EJ, Hooper RL, et al. Measurement of quality of life in alcohol-dependent subjects by a cancer symptoms checklist. Alcohol 2000; 20: 105-110.

10. Foster JH, Marshall EJ, Peters TJ. Comparison of the quality of life of cancer patient and alcohol dependents. Qual Life Res 1997; 6: 646-646.

11. Stein MD, Mulvey KP, Plough A, et al. The functioning and well being of person who seek treatment for alcohol use. J Subst Abuse 1998; 10: 75-84.

12. Smith Kw, Larson MJ. Quality of life and substance use: concept and recent tendencies. Curr Opinion Psych 2009; 22: 281-286.

13. Volk R, Cantor S, Steinbauer J, et al. Alcohol use disorders: comsumption patterns, and health-related quality of life primary care patients. Alc Clin Exp Res 1997; 21: 899-905.

14. Patience D, Buxton M, Chick J, et al. The SECCAT Survey: II The Alcohol Related Problems Questionnaire as a proxy for resource costs and quality of life in alcoholism treatment. Study of socio-economic consequences and costs of alcoholism and treatment. Alcohol 1997; 32: 79-84.

15. Daeppen JB, Kreig MA, Burnand B, et al. MOS-SF-36 in evaluating health-related quality of life in alcohol-dependent patient. Am J Drug Alcohol Abuse 1995; 24: 685-694.

16. Polak K. Ocena jakości życia żołnierzy zawodowych z rozpoznanym zespołem zależności alkoholowej. Psych Pol 2001; 6: 1057-1070.

17. Rudolph H, Bommer I, Priebe S. Alcoholic women after withdrawal - how do they assess their living-situation? Wien Z Suchtforsch 1996; 19: 47-53.

18. Wnuk M. Porównanie poziomu poczucia koherencji oraz jakości życia anonimowych alkoholików i studentów nadużywających narkotyków. Psychiatr Psychol Klin 2010; 10: 96-102.

19. Rudolph H, Priebe S. Similarities and differences in subjective quality of life of alcoholic women. Psychiatr Prax 1999; 26: 116-121.

20. Gillet C, Paille F, Wahl D, et al. Outcome of treatment in alcoholic women. Drug Alcohol Depend 1991; 29: 189-194.

21. Wnuk M. Zaangażowanie w ruch samopomocy a poczucie jakości życia osób uzależnionych od alkoholu. Mediacyjna rola poczucia sensu życia. Alkoholizm i Narkomania 2006; 19: 357-368.

22. Trzebiatowski J. Jakość życia trzeźwiejących alkoholików a skuteczność programów AA i placówek leczenia uzależnień. Alkoholizm i Narkomania 2010; 23: 217-235.

23. Chodkiewicz J. Ocena jakości życia alkoholików przed i po terapii odwykowej. Co zmienia się w czasie leczenia? Alkoholizm i Narkomania 2012; 25: 133-150.

\section{Address for correspondence:}

Zbigniew Śliwiński

Faculty of Health Sciences

Jan Kochanowski University

al. IX Wieków Kielc 19, 25-317 Kielce, Poland

Phone: +48 602475408

E-mail: dr_sliwinski@post.pl 